\title{
The Applications of BOT Mode on the Development of Public Golf Course in China
}

\author{
Yao Zou \\ International Education College in Wuhan Institute of \\ Physical Education, Hubei Wuhan, China \\ The Member of Sports Information Research Center \\ 87877000@qq.com,
}

\begin{abstract}
Based on the methods of literature, field investigation, expert interview, mathematical statistics, system analysis and case studies, this article focuses on the analysis of the feasibility of BOT mode in the development of public golf course in China, the process of operation, the coordination mechanism of market and government, the interaction mechanism of the market and the government and six key factors of successful operation system.
\end{abstract}

\section{Keywords-BOT; Mode; Public golf course}

\section{INTRODUCTION}

BOT is the abbreviation form of " Build-OperateTransfer”. The concept of BOT, which was applied into the Turkey's national public sector project by Prime Minister TURGUTOZAL in 1990, was initially formed in 1984

( Tiong,R.L.K., 1990) . On the basis of agreements between government and private institution, promulgated charter by the government, BOT, which is a way of infrastructure investments, construction and operation, means that private institution will raise money to construct and pay attention to the management and operation of its corresponding facilities, products and services. Although the government can limit the quantity or the prices of the products or services, it will guarantee that profit opportunities can be obtained by private institution, and that the risks of whole process can be shared by government and private institutions. By the end of the concession period, all of facilities will be transferred to the government and be managed by the government department. This mode has been widely used in some developing countries on the basis of characteristics of non-fund for government, Clear boundaries of rights, responsibilities and profits, the stability of project returns and the pervasiveness of services. during the past 20 years, This mode has been applied into the following fields: the supply of urban water, the conservation of water, heat supply, gas supply, public transport, the project of roads, bridges and tourisms and large projects for sports infrastructure.

Nowadays there are some researches involving the field of public golf course at home and abroad. Shenzhen Stadium of Light has become the first public golf course adopting BOT mode to the construction, operation and management of golf course in China. Li Guangzhen, the chairman of Shenzhen Golf Association, contends that Shenzhen Stadium of Light, whose characteristic belongs to a typical government-market coordinated development pattern, is invested by private enterprise and will be transferred to

\author{
Zhiyong Huang \\ Economics and Management College, Wuhan Institute of \\ Physical Education, Hubei Wuhan, China \\ 419214631@qq.com
}

government after 50 years. (Li Guangzhen, 2010) Based on the principle of "first class quality, superior enjoyment", Shenzhen Stadium of Light has provided high-quality golf course, elegant club, first class management staff and superior service for all of golf players. since it opened in 2005, Shenzhen Stadium of Light has achieved outstanding merits in the social benefit and also won many honors and prizes, such as, the prize of "Passionate Support "in 2006 from National Golf Association, the honor of "One of Top Ten Influential Golf Clubs" issued by the Beijing Great Hall of the People in 2007, and the title of "the Most Popular Club" in 2007 and 2008, all of these honors boost stadium to reap economic benefits in return. Here I will focus on the discussion on the applications of BOT of Public Golf Course in China.

\section{THE FEASIBILITY ANALYSIS OF APPLICATIONS OF BOT ON THE DEVELOPMENT OF PUBLIC GOLF COURSE IN CHINA}

Since the first golf club was born in the mainland of China in 1984, the situation of the facilities of Chinese golf course has improved a lot. The statistics show that there have been 521 golf facilities by the end of 2013, compared with 2012, the rate has increased by $9.2 \%$.(Forward Group, 2014). Golf industry market in China has begun to take shape. But the overwhelming golf stadiums are dominated by the policy of membership, while there are only 7 public golf courses in China which cover $1.34 \%$ of the total numbers(Huang Zhiyong,2011). Among these seven stadiums, Shenzhen Stadium of Light is the only one who has adopted the BOT mode. The insufficiency of the supply of public golf course seriously hindered the development and popularization of Chinese golf. Through analyzing the case of Shenzhen Stadium of Light in the mode of BOT, this thesis aims at the feasibility study of the theory and practice for the future development and construction of the public golf course in China.

Firstly, the BOT mode is suitable for financial needs for the infrastructure of public stadiums which have large investment scale, high technical requirements, long construction period and high operation risk; Secondly, Nations have no risks on debts because there are no recourse or limited recourse in the project financing, therefore the debt is not included in the national debt; Thirdly, the project, whose financing methods are the construction and management of privileges to other commercial capital or private capital, is called "franchises project ". Fourthly, the diversification of investment subject and risk sharing and 
management are the main characteristics; Fifthly, the government commonly can give corresponding support and help in the model of BOT, such as land use, loan, tax, construction, water and electricity, urban planning, etc. Therefore, the government's various incentives and support policies within limited franchise options will provide great competitive advantage so that the stadiums can get huge

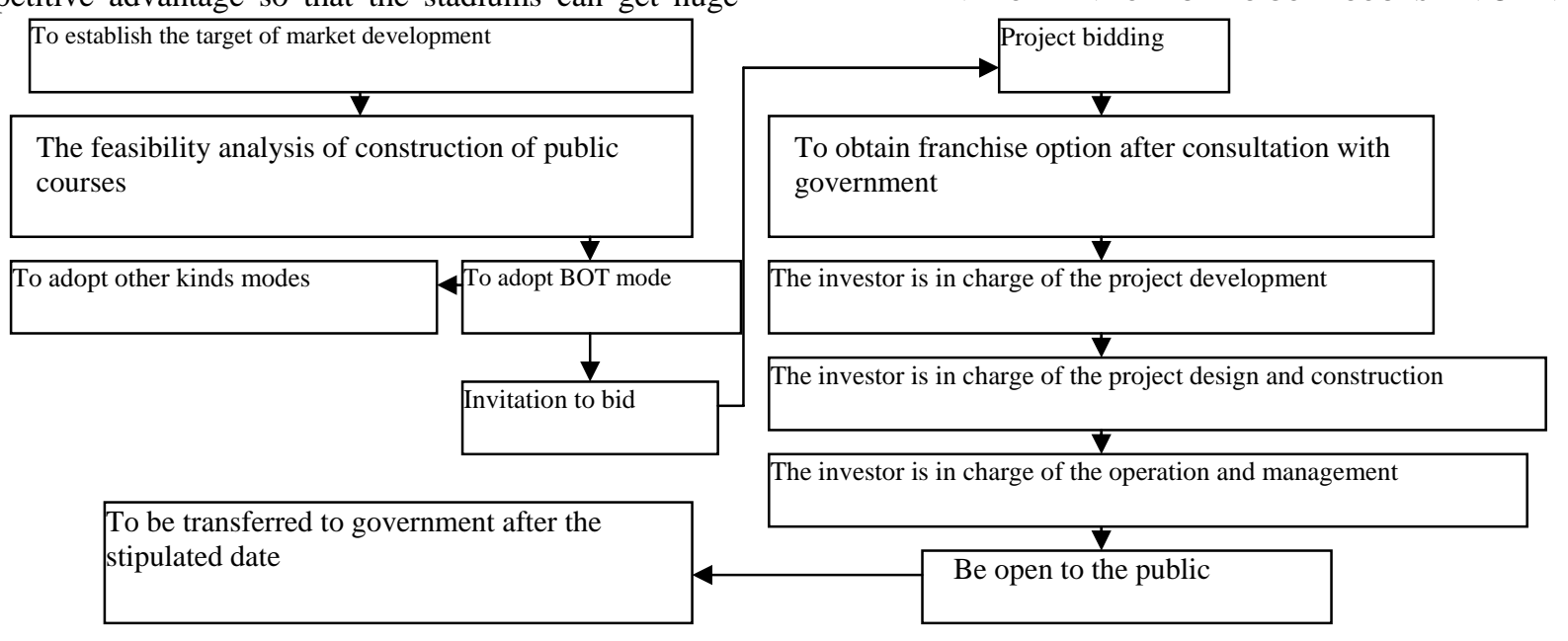

Figure 1. The chart of the development process of BOT mode for the public golf courses.

Specific process of the application of BOT mode in the public golf courses, which is involved in the aspects of the feasibility analysis, project bidding, the consultation of franchise option, the development, construction and management of public stadium and the connection between stadiums and government, are shown in the following table.

IV THE COORDINATION MECHANISM BETWEEN

MARKET AND GOVERNMENT DURING THE PROCESS OF APPLICATION OF BOT MODE INTO THE PUBLIC GOLF COURSE economic benefits in a short time; for the government, he will obtain a complete and mature operating public golf course freely; for the general public and golf fans , they will enjoy benefits a lot too, why not do it!

III THE APPLICATION OF BOT MODE IN THE PROCESS OF THE DEVELOPMENT OF PUBLIC GOLF COURSE IN CHINA
To obtain franchise option after consultation with government

Making full use of positive interaction mechanisms between market and the government can promote the development of public course on the basis of BOT mode. During the transition from the single economic function to multifunction, the asymmetry between the diversity of market developer and the commonality of operating forms results in the conflicts between private developers or companies who are in pursuit of maximization of profit and the government who are after the maximization of welfare. Therefore, the main goal of establishing interactive mode between market and government is to coordinate, to eliminate or to weaken internal conflict and promote its benign and sustainable development. As shown in figure 2 .

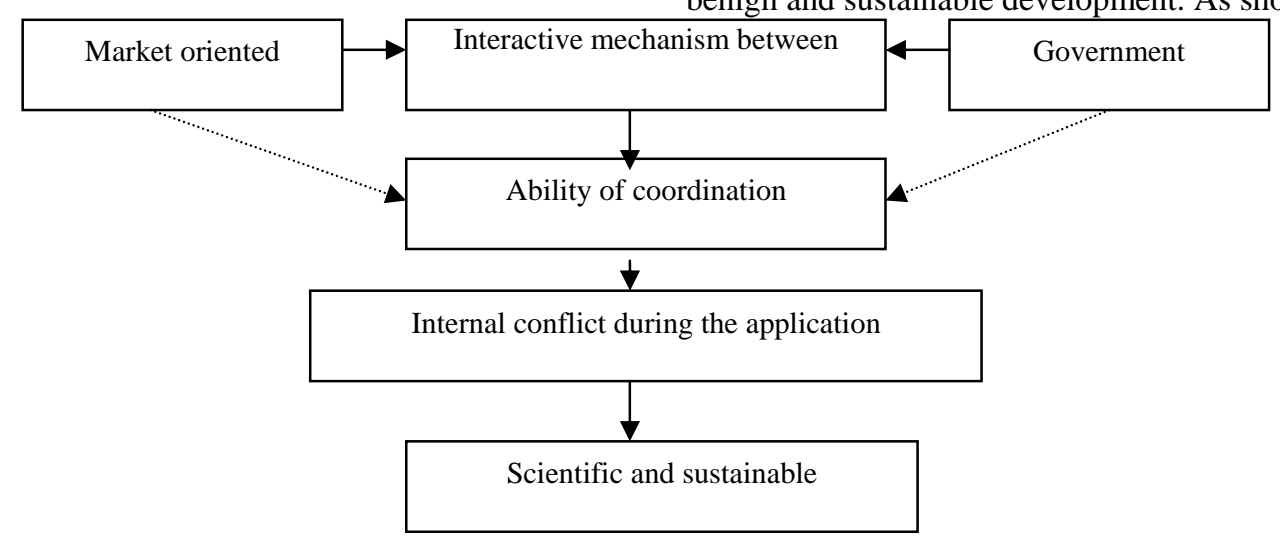

Figure 2. The chart of sustainable development relationship between coordination mechanism of market - government and public golf course 
V THE INTERACTION MECHANISM OF THE MARKET

AND THE GOVERNMENT DURING THE PROCESS OF

APPLICATION OF BOT MODE INTO THE PUBLIC GOLF COURSE

IN CHINA

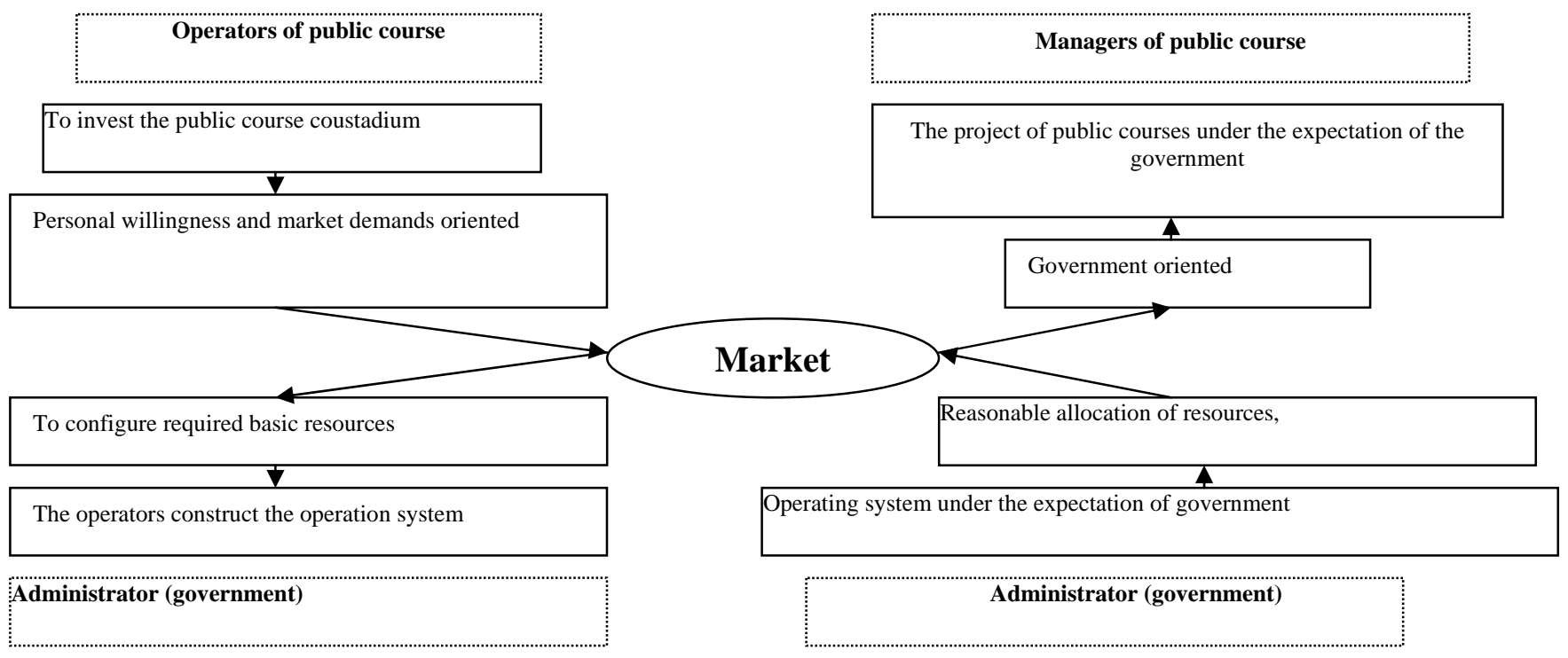

Figure 3. The process of Interactive mechanism of market - government

Under the condition of current market economy system, There are two main winner of interests during the application of BOT mode. One is the operators of public stadium, here namely private institution, social community and relevant enterprises; the other is relevant government agency. Based on the coordination of market mechanism, the managers and operators influence each other, adjust their behavior, and contribute to the consistence and harmony. The interaction mechanism of market - government is mainly based on market information. as shown in figure 3 . the developers and the operators can choose any projects according to the local resources situation and their willingness to invest and develop BOT mode, to provide the appropriate price, consumption mode, service mode, and other supporting project, to buy required production resources in the later process of the operation and maintenance so as to realize the moneymaking and sustainable operation. This means that the public stadium operating system is formed.

As for the government who is the main management organization of industry, making use of its administrative power to take measures and guiding the healthy development of the entire golf industry is their bounden duty. At present the government's main measures include options of franchising, relevant policy support, the preferential tax policy, investment and credit policy and other economic leverage, etc. If the developers and operators of public stadium can understand the intentions of government, they will adjust their operation ways and establish the public stadium project.
VI THE KEY FACTORS OF SUCCESSFUL OPERATION OF BOT MODE IN THE DEVELOPMENT OF PUBLIC GOLF COURSE

\section{A The promise of government for concession period}

Through consultation between government and investors, the government will make a promise to grant investors to run the power for the public stadium within the scope of a certain time limit in order to recoup their investment and reach the agreement, and the length of the concession period directly affects the return of investors. For investor, the longer, the better. Generally speaking, the concession periods ranging from 20 to 50 years are different to some degree.

\section{B Purchasing Guarantee}

Characterized by large investment and long payback period, the vast majority of income of public course comes from the consumption or other sales income of other facilities services. during the operating period, investors should be given the purchasing guarantee in the process of legal operation, and have the chance to run independent and scientific operation.

\section{$C$ The promise for restriction of competition}

The promise for restriction of competition usually means government won't approve the similar public stadium project at a certain time or geographical range. Investors will emphasize the guarantee from government because of various risks they will face with in the long concession period. These risks result in the uncertainty which makes the obtain the reasonable profits. This promise is the key to 
investor burdened the risk independently or faced with fierce competition from competitors.

Therefore, the promise for restriction of competition has become the effective guarantee of earning profits. This guarantee is usually divided into two different forms, one is that the government will not make a approval in certain region, the other is in certain range of time.

\section{$D$ The guarantee for the price adjustment}

The guarantee for the price adjustment means that the government makes a promise for price adjustment according to certain rules in a certain time or in certain cases. Reasonable approach is to allow the investors to adjust the consuming price along with the changes of the economic environment. The government also has the right to adjust and control the fluctuation of prices which will not be very high. Price adjustments can be roughly divided into two forms, one kind refers to the price adjustment which is finished on the basis of government approval after the proposal of investor. The other means that the government can carry out the policy of price adjustment independently on the basis of the form of contract. The first way is the most beneficial for the government, but investors prefer to choose the second option.

\section{E To keep the balance between social benefit and economic benefit}

Taking the limited franchise period into consideration, the enterprise should obtain investment returns through scientific management and operation independently; on the other hand, they also have to pay attention to the build of the brand image for the social benefit so as to promote the sustainable development. Taking Shenzhen Stadium of Light as a example, since it opened in 2005, It has boost the stadium to reap economic benefits in return and also won many honors, such as the honors I have mentioned in the introduction."In the pursuit of economic benefits, The Light pay attention to the cost control." according to general manager Wang Ruisuo, "The expenditure of human resources is the biggest part of the total cost, under the policy of on-demand position, the stadium promote the subjective initiative of each department and each employee. "he also especially emphasized "the streamlined configuration is very important, but we won't save in management and maintenance of the course, in order to ensure the high quality of turf and the services to customers, we have done a lot of jobs on the high utilization of machineries, careful maintenance of the equipments,, and the environmental protection of pesticides or fertilizer, etc.”

\section{F Other related land leasing, tax incentives and other protection}

In addition to ensure the smooth running of BOT mode, the government will also provide preferential treatments and policies on the following aspects, such as land leasing, demolition, taxes, loans and other infrastructure construction.

\section{CONCLUSION}

BOT mode in the development of the Chinese public golf course already has certain theory and practical experience, in the future, we also can use other similar modes for the development of public courses, such as BOOT (Build - own - operate - transfer), BOO (build - own operate) and BTO (build - transfer - operate) and so on.

\section{REFERENCES}

[1] Tiong, R.L.K. Comparative Study of BOT Projects[J]. Journal of Management and Engineering, 1990, 6(1):107-120.

[2] Li Guangzhen. Speech on the Construction of Golf Course in Guangdong Province[Z]. 2010-03-30

[3] Forward Group. Report on China's Golf Industry[R].2014:19-79.

[4] Huang Zhiyong. Research on the Driving Mechanism and Development Modes of the Public Golf Course in China [D].Beijing: Beijing Forest University, 